\title{
How important are health and education in boosting sub- national economic growth?
}

\author{
Verazulianti, Taufiq Carnegie Dawood* and Teuku Zulham \\ Faculty of Economic and Business, Syiah Kuala University, Banda Aceh, Indonesia \\ *Correspondence email: taufiq.dawood@unsyiah.ac.id
}

\section{ARTICLE INFO}

- Research Article

Article History

Received 28 November 2020

Accepted 19 January 2021

Published 1 April 2021

\section{Keywords}

education outcome; GMM; health outcome; sub-national growth

JEL Classification
H51; H52; O15

\begin{abstract}
Recent development of the global economy is marked by increasing attention towards the health sector. This research contributes to how important are health and education for provincial economic growth, and connects it with foreign direct investments and public infrastructure spending. Taking Indonesia as a case study and employing GMM method, the analysis found that improving health and education outcomes is key for sub-national economic growth. However, foreign direct investment, domestic direct investment, and public spending on infrastructure failed to support growth in the sub-national level. The finding is robust against alternative specification. For policy suggestions, in order to dampen the negative effects of the recent global economic downturn and to boost growth at post-downturn period, government at all levels must maintain or even increase public spending in health and education which directly target improvements of health and educational outcomes. To ensure the improvements, public spending must be directed to provide good quality health and educational services, i.e. services which enhance health outcomes and develop students' cognitive skills. In addition, good quality health and educational services must be evenly distributed across sub-nationalities.
\end{abstract}

To cite this article: Verazulianti, Dawood, T. C., \& Zulham, T. (2021). How important are health and education in boosting sub-national economic growth? Journal of Socioeconomics and Development, 4(1), 33-45. https://doi.org/10.31328/jsed.v4i1.1762

ISSN 2615-6075 online; ISSN 2615-6946 print (CUWG Press, 2021

\section{INTRODUCTION}

Indonesia is a large country, but the economic development among its regions are not evenly distributed. Based on data from World Development Indicators, Indonesia is the fourth most populated country in the world, the third largest nation in the Asia-Pacific, and the largest country in Southeast Asia in terms of population. According to OECD database, Indonesia is a member of the Organization of Economic Cooperation and Development (OECD). Equitable distribution of regional economic development within a country is an important economic objective for a developing economy like Indonesia. However, economic development among regions in the country has not been evenly distributed (Panjawa, Samudro, \& Soesilo, 2018).

Economic development is influenced by developments in the social sector. The social sector includes the health sector (Umar, 2017) and the education sector (Ogundari \& Awokuse, 2018). In addition, development is also influenced by the availability of financing (Dawood, Pratama, Masbar, \& Effendi, 2019) and public spending (Ambya, 2020; Elia, Yulianto, Tiawon, Sustiyah, \& Indrajaya, 2020). 
There were studies which showed that health outcomes affected a country's economic growth. Ogundari \& Awokuse (2018) found that health outcome was positively related to economic growth in Sub-Saharan African countries. Similarly, Spiteri \& Von Brockdorff (2019) found that health outcome had a positive relationship with economic growth in European countries. Biyase \& Maleka (2019) found that health outcome (as measured in life expectancy) contributed positively to economic growth in Southern African Development Community countries. Likewise, $\mathrm{He}$ \& Li (2020) found a positive relationship between health outcome (as measured in life expectancy) and economic growth in a panel study of 65 countries. The health sector is a means of investment to create human capital (Collin \& Weil, 2020). Previous studies show that human capital is needed for the acceleration of economic growth (Teixeira \& Queirós, 2016a). The presence of high quality human resources can be allocated and utilized to create added value in the economy (Yudawisastra, Garlinia, Manurung, \& Husnatarina, 2018).

In addition to health, educational outcome is also essential for economic growth of a country. There was a positive relationship between educational outcome and economic growth in European Union member countries (Pribac \& Anghelina, 2015), the OECD countries (Teixeira \& Queirós, 2016b), SubSaharan African countries (Ogundari \& Awokuse, 2018), and Azerbaijan (Ismayilov, Kasumov, \& Ahmadova, 2020). On the contrary, Afzal, Farooq, Ahmad, Begum, \& Quddus (2010) found a short-run negative relationship between education and growth in Pakistan. In the same light, Adawo (2011) found that secondary and tertiary education actually reduced economic growth in Nigeria. Whereas, Mendy \& Widodo (2018) found that the relationship between secondary education and economic growth in Indonesia was negative. Like health, education is an investment channel to create human capital. Likewise, human capital is a key determining factor for economic growth in a country via allocation of the human capital to economic sectors to create added value (Teixeira \& Queirós, 2016a).

In addition, bank credit is also important for growth. Such studies discovered in many countries as Nigeria (Judith, Ugwuegbe, \& Ugwuoke, 2014), India (Sehrawat \& Giri, 2015a), and United States (Hartarska, Nadolnyak, \& Shen, 2015) showed that bank credit had a positive and significant impact on economic growth. The reason that bank credit is pivotal for a country's economic growth is that the development of various economic sectors requires financing services (Dawood et al., 2019). Meanwhile, bank credit is the most important source of financing for developing countries (Dawood, 2018). Furthermore, the role of banking in economic growth is very crucial because it is a source of financing for economic activities both in the national scope (Benczúr, Karagiannis, \& Kvedaras, 2019) and in the sub-national level (Soedarmono, Hasan, \& Arsyad, 2017).

A positive relationship between government spending and economic growth has been widely studied. Chu, Hölscher, \& McCarthy, 2020; Musa \& Jelilov (2016) found a positive relationship between government spending and economic growth. Whereas, Ambya (2020) found that local government spending had a positive effect on the economic growth in these areas. However, Sáez, ÁlvarezGarcía, \& Rodríguez (2017) found that government expenditures had no significant impact on growth in European Union countries.

Table 1. Government Spending in Indonesia, 2018

\begin{tabular}{lcc}
\hline Spending & \multicolumn{2}{c}{ Expenditure Budget } \\
\hline & trillion rupiah & $\%$ \\
Government Spending & $2,220.7$ & \\
Total Regional Government & $1,107.6$ & 49.87 \\
$\quad$ Spending & & \\
Central Government Spending & $1,113.1$ & 50.13 \\
\hline
\end{tabular}

Source: Ministry of Finance of Indonesia (and authors' calculations)

Government spending tends to be followed by growth, while sub-national level governments' spending makes up half of total public spending. Public spending has an important impact on national economic growth (Chu et al., 2020) and also toward sub-national economies (Ambya, 2020). As a note, public spending by sub-national governments is a significant portion of total government spending and accounts for half of nation-wide public spending in Indonesia (Table 1).

Government spending supports a variety of development financing such as infrastructure, investment climate and quality of human resources. This prompts economic growth at the national and sub-national levels. Studies were conducted by researchers (Ansar, Flyvbjerg, Budzier, \& Lunn, 2016; Saidi, Shahbaz, \& Akhtar, 2018; Shi, Guo, \& Sun, 
2017) found relationship between road construction spending and economic growth. Meanwhile, other studies found a positive relationship between Foreign Direct Investment (FDI) and economic growth (Ali \& Mna, 2019; Bakari, 2017; Hlavacek \& Bal-Domanska, 2016; Bakari, 2017; Ali \& Mna, 2019). Research by Lubis (2014) found that the number of workers had positive and significant effect on economic growth in Indonesia. Similarly, Putri (2014) found that the number of workers had positive impact on economic growth in provinces in the island of Java, Indonesia. Likewise, Ahmed, Mahalik, \& Shahbaz (2016) found a positive relationship between the number of workers and economic growth in Iran. In addition, a positive relation was found between labor and growth in Malaysia (Ramli, Hashim, \& Marikan, 2016).

Current development of the global economy is marked by increasing attention towards the health sector as the result of the Covid-19 pandemic. Like many countries in the world, Indonesia suffers from increasing rates of Covid-19 cases (Nugroho, 2020). Likewise, Indonesia increased its attention to the health sector as shown by the sizeable increase in government spending in this sector (Silalahi \& Ginting, 2020). This trend in government spending has important impact on Indonesia's economic development both in the national (Hadiwardoyo, 2020) and sub-national level (Maryanti, Netrawati, \& Nuada, 2020).

Based on the arguments, apart from existing research which analyzed the effect of health, education and other variables towards economic growth in the national level, there is yet to be a study assessing how important are health and education outcomes, compared to other variables, in boosting economic growth in the sub-national level, particularly for Indonesia. This question has important practical implications, specifically for developing countries like Indonesia. Policy makers both in the central and sub-national levels, in the effort to develop their areas, currently face intricate policy choices due to constrained public budget, especially when confronted with the current Covid-19 pandemic.

This research aims to fill this gap in the literature by analyzing how important are health plus education outcomes, compared to other variables, for subnational economic growth, in the context of Indonesia.

\section{RESEARCH METHOD}

The data used in this study is a panel of 33 provinces in Indonesia spanning from 2010 to 2018. As a note, starting from 2012, there are 34 provinces in Indonesia (statistical data since 2013). One addition is North Kalimantan, which previously was a part of East Kalimantan. However, to maintain a balanced panel data set, North Kalimantan was not included in the analysis.

The variables used in the current study were transformed to growth rates to ensure stationarity of the data. The abbreviation for economic growth rate of provinces in Indonesia is gPDRB, growth of bank credit is gCB, growth of FDI is gFDI, growth of provincial government expenditure is $\mathrm{gGE}$, growth of provincial government infrastructure expenditure is gGEin, growth of health outcome (measured by life expectancy) is $\mathrm{gHl}$, growth of education outcome (measured by years of schooling) is gEdu, and growth of labor is $\mathrm{gL} . \gamma_{1}$ is defined as constant term, $\gamma_{i}$ as the estimated coefficients, $e_{i, t}$ as the error term; $i$ as the index for province $i$, and $t$ as the year. Following Gujarati \& Porter (2009), the empirical model for this study was written as follows.

$$
\begin{aligned}
& \mathrm{gPDRB}_{\text {it }}=\gamma_{1}+\gamma_{2} \mathrm{gCB}_{1 \mathrm{it}}+\gamma_{3} \mathrm{gFDII}_{2 \mathrm{it}}+\gamma_{4} \mathrm{gGE}_{3 \mathrm{it}} \\
& +\gamma_{5} \text { gGEin }_{4 i t}+\gamma_{6} g \mathrm{HI}_{5 i t}+\gamma_{7} \mathrm{gEdu}_{6 i t} \\
& +\gamma_{8} \mathrm{gL}_{7 \mathrm{it}}+e_{\mathrm{it}}
\end{aligned}
$$

The choice of variables was adapted from the previous work (Ambya, 2020) by adding health and education outcomes, bank credit, and investment. The data used were annual data from 33 provinces in Indonesia. Data on PDRB, health outcomes $(\mathrm{HI})$, educational outcome (Edu), government expenditures (GE), and labor (L) were obtained from the Central Statistical Bureau of Indonesia (BPS), data on bank credit (CB) were obtained from The Indonesian Authority of Financial Services (OJK), data on Government spending for infrastructure (GEin) were obtained from The Ministry of Finance of Indonesia, and data on FDI were obtained from The Investment Coordination Agency of Indonesia.

This study applies the panel difference Generalized Method of Moments (GMM) estimates. The reason to apply the panel GMM method is to handle issues of endogeneity. For the panel GMM method, one-period lag of the regressors were used as instruments. 
The data are stationary in growth form. Table 2 shows the unit root stationarity test using various approaches; LLC, IPS, ADF-Fisher, and PP-Fisher.

Table 2. Panel Unit Root Test

\begin{tabular}{lrrrr}
\hline Ta & \multicolumn{4}{c}{ Individual Intercept } \\
\cline { 2 - 5 } & LLC & \multicolumn{1}{c}{ IPS } & ADF-Fisher & PP-Fisher \\
\hline gPDRB & -15.782 & -3.374 & 121.053 & 128.594 \\
p-value & 0.000 & 0.000 & 0.000 & 0.000 \\
gCB & -6.237 & -0.178 & 85.536 & 284.255 \\
p-value & 0.000 & 0.430 & 0.053 & 0.000 \\
gFDI & -9.200 & -2.735 & 101.905 & 211.382 \\
p-value & 0.000 & 0.003 & 0.001 & 0.000 \\
gGE & -23.358 & -2.954 & 108.515 & 173.794 \\
p-value & 0.000 & 0.002 & 0.001 & 0.000 \\
gGEin & -10.865 & -1.206 & 88.483 & 192.870 \\
p-value & 0.000 & 0.114 & 0.034 & 0.000 \\
gHI & 0.577 & -0.670 & 97.441 & 99.863 \\
p-value & 0.718 & 0.252 & 0.007 & 0.005 \\
gEdu & -7.646 & -1.450 & 93.156 & 172.028 \\
p-value & 0.000 & 0.074 & 0.016 & 0.000 \\
gL & -12.506 & -3.676 & 118.697 & 307.596 \\
p-value & 0.000 & 0.000 & 0.000 & 0.000 \\
\hline
\end{tabular}

Values of the statistics and their respective $p$ values in Table 2 shows that growth of PDRB (gPDRB), bank credit $(\mathrm{gCB})$, FDI, health $(\mathrm{gHI})$, education ( $g E d u)$, government spending ( $g G E)$, infrastructure spending ( $\mathrm{gGEin}$ ) and labor $(\mathrm{gL})$ are stationary.

Table 3. Variance Inflation Factor

\begin{tabular}{lccccccc}
\hline & & EDU & HI & Gein & FDI & L & GE \\
\hline \multirow{4}{*}{ CB } & & & & & & & \\
& $R^{2}$ & 0.17 & 0.14 & 0.70 & 0.55 & 0.23 & 0.42 \\
& VIF & 1.20 & 1.16 & 3.32 & 2.24 & 1.31 & 1.73 \\
EDU & $\mathrm{R}^{2}$ & & 0.22 & 0.18 & 0.05 & 0.02 & 0.02 \\
& VIF & & 1.28 & 1.21 & 1.06 & 1.02 & 1.02 \\
HI & $\mathrm{R}^{2}$ & & & 0.08 & 0.13 & 0.14 & 0.02 \\
& VIF & & & 1.08 & 1.14 & 1.16 & 1.03 \\
Gein & $\mathrm{R}^{2}$ & & & & 0.25 & 0.03 & 0.33 \\
& VIF & & & & 1.33 & 1.03 & 1.49 \\
FDI & $\mathrm{R}^{2}$ & & & & & 0.35 & 0.25 \\
& VIF & & & & & 1.55 & 1.33 \\
$\mathrm{~L}$ & $\mathrm{R}^{2}$ & & & & & & 0.15 \\
& VIF & & & & & & 1.18 \\
\hline
\end{tabular}

Table 4. Autocorrelation Test for GMM

\begin{tabular}{lcccc}
\hline Test order & $\begin{array}{c}\mathrm{m} \text { - } \\
\text { Statistic }\end{array}$ & rho & SE(rho) & P-value \\
\hline $\mathrm{AR}(1)$ & -2.04050 & -0.03770 & 0.01848 & 0.041 \\
$\mathrm{AR}(2)$ & 0.89054 & 0.00480 & 0.00539 & 0.373 \\
\hline
\end{tabular}

To test the multicollinearity, Variance Inflation Factor test (VIF) was employed. As displayed in Table 3, the values of VIF is less than 10 in all cases. Thus, the model did not suffer from multicollinearity.
The panel GMM estimated if the choice of instruments was appropriate and did not suffer from autocorrelation. For the panel difference GMM estimates it was found that the probability value of the Hansen J-statistic is 0.267 (Table 5). Since the pvalue of the J-statistic was greater than 0.05 , the choice of instruments (one-period lagged regressors) was appropriate. While for autocorrelation, based on the Arellano-Bond serial correlation test, the errors did not suffer from autocorrelation for the autoregressive of order 2 (AR(2)) (Table 4).

\section{RESULT AND DISCUSSION}

\section{Health, Education and Economic Growth in Sub-nationalities in Indonesia}

Equitable distribution of regional economic development within a country is an important economic objective for a developing economy like Indonesia. However, economic development among regions in the country has not been evenly distributed (Panjawa et al., 2018). This is as indicated by the share of Gross Regional Domestic Product (PDRB) of the provinces, where the national economy are dominated by provinces in the islands of Java and Sumatra. Figure 1 shows that in the first quarter of 2019, the PDRB of provinces in the island of Java\% was $59.03 \%$ of total Indonesia's Gross Domestic Product. This share is followed by PDRB shares of the provinces on the islands of Sumatra (21.36\%), Kalimantan (8.26\%); Sulawesi (6.14\%), Bali and Nusa Tenggara (3.02\%), and lastly Maluku and Papua (2.19\%).

Sub-national economic growth tends to follow growth in health outcomes. The health sector is a means of investment to create human capital (Collin \& Weil, 2020). Meanwhile, human capital is needed for the acceleration of economic growth (Teixeira \& Queirós, 2016a). The presence of high quality human capital can be allocated and utilized to create added value in the economy (Yudawisastra et al., 2018). The trend of PDRB growth and growth in health outcome (measured by life expectancy) in Indonesia is presented in Figure 2. As illustrated in Figure 2, PDRB growth and health outcome growth in Indonesia tend to follow each other. Since 2011, the growth in health outcomes has shown a downward trend. Likewise, PDRB growth rate has shown a downward and stagnant trend since 2012. 


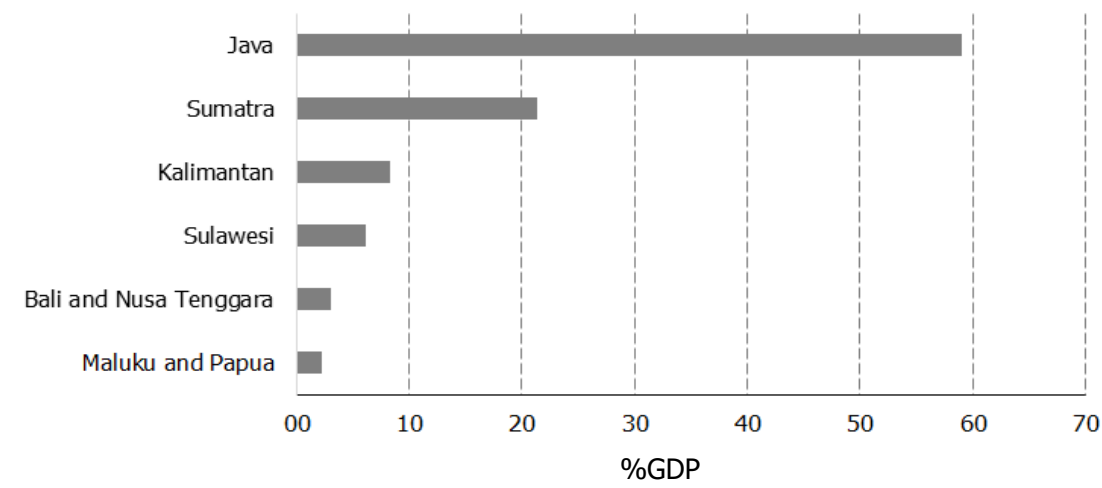

Figure 1. Regional contribution to the national GDP of Indonesia in the 1st quarter of 2019 Source: Central Statistical Bureau of Indonesia and authors' calculations.

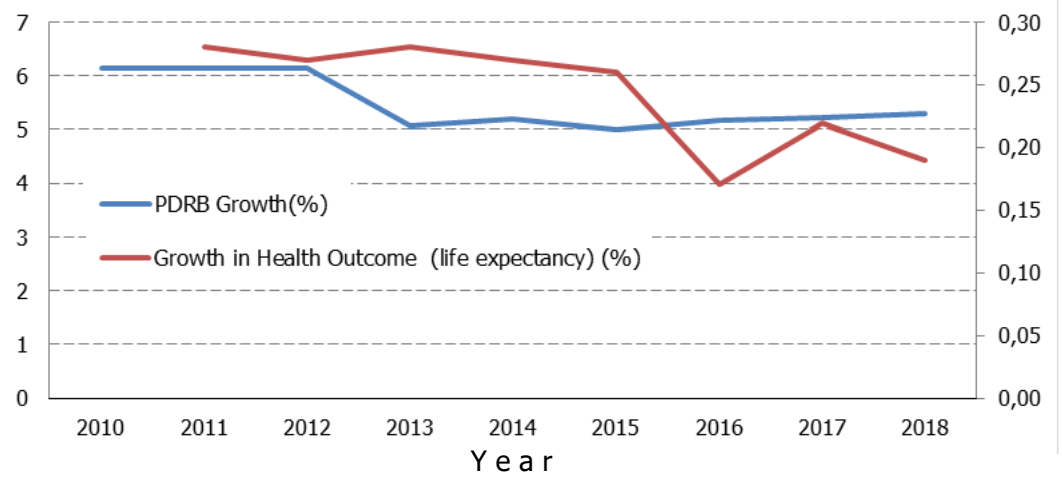

Figure 2. Economic growth and health outcome growth, 2010-2018 Source: Central Statistical Bureau of Indonesia and authors' calculation

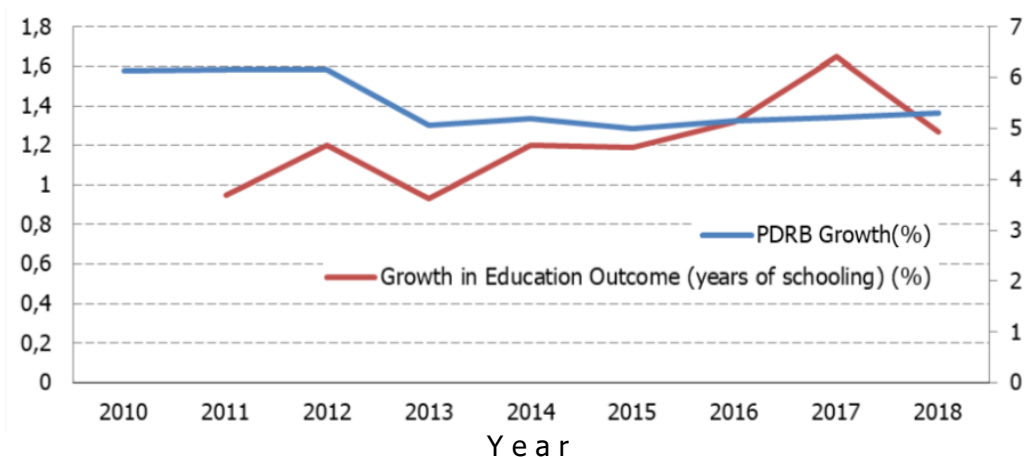

Figure 3. Economic growth and year of schooling growth, 2010-2018 Source: Central Statistical Bureau of Indonesia and authors' calculations. 
Educational outcome tends to grow overtime, however economic growth in the sub-national level did not follow suit. Like health, education is an investment channel to create human capital. Meanwhile, human capital is a key determining factor for economic growth in a country (Teixeira \& Queirós, 2016a) and in the sub-national level (Faggian, Modrego, \& McCann, 2019). Figure 3 shows the development of PDRB and growth in education outcome (measured by years of schooling) in Indonesia. In this figure, it can be viewed that growth of education outcome has had an increasing trend since 2011. However, unlike education, PDRB growth rate has tended to be stagnant since 2012 .

\section{Estimation Results}

This section presents estimation results in the study. As shown in Table 5, bank has a positive and significant effect on economic growth (gPDRB) of provinces in Indonesia. This result is in line with the findings in the case of Turkey (Önder \& Özyıldırım, 2013), Indian states (Sehrawat \& Giri, 2015b) and Cameroon (Belinga, Zhou, Doumbe-Doumbe, Gahe, \& Koffi, 2016).

Table 5. The Estimated Findings and Robustness Check

\begin{tabular}{lccccc}
\hline \multirow{2}{*}{ Variable } & \multicolumn{2}{c}{ GMM 1 } & & \multicolumn{2}{c}{ GMM 2 } \\
\cline { 2 - 3 } \cline { 5 - 6 } & Coeff & p-value & & Coeff & p-value \\
\hline gPDRB(-1) & 0.0721 & 0.000 & & 0.0765 & 0.000 \\
gCB & 0.0673 & 0.000 & & 0.0700 & 0.000 \\
gEdu & 0.1992 & 0.044 & & 0.1867 & 0.089 \\
gHI & 2.7820 & 0.000 & & 2.6486 & 0.000 \\
gGEin & -0.0000 & 0.000 & & -0.0000 & 0.000 \\
gFDI & -0.0002 & 0.529 & & \\
gDDI & & & & 0.0002 & 0.260 \\
gL & 0.0004 & 0.005 & & 0.0003 & 0.000 \\
gGE & 0.0002 & 0.080 & & 0.0001 & 0.183 \\
\hline J-statistic & & 16.806 & & & 15.415 \\
Prob(J-statistic) & & 0.267 & & 0.350 \\
AR(1) p-value & & 0.041 & & 0.050 \\
AR(2) P-value & & 0.373 & & 0.438 \\
\hline
\end{tabular}

Health sector also has positive impact in spurring the sub-national economy, plus it is highly important for boosting growth. As shown in Table 5 (GMM1), the panel GMM estimates found that health outcome $(\mathrm{gHI})$ has a positive and statistically significant influence on economic growth in the sub-national level (gPDRB). This finding is in line with the conclusion obtained by $\mathrm{He} \mathrm{\&} \mathrm{Li} \mathrm{(2020)}$ in a crosscountry panel data study, in Southern African
Development Community member countries (Biyase \& Maleka, 2019) and for the provinces in Indonesia's Kalimantan Island (Safira, Djohan, \& Nurjanana, 2019). In addition, Table 5 (GMM1) shows that the impact of growth in health outcomes on economic growth in the provinces in Indonesia is approximately 40 times larger than the effect of bank credit on subnational economic growth.

Education has a positive and significant impact on sub-national economic growth. Based on the GMM estimation result, the study finds that the growth of education outcome (measured in years of schooling) (gEdu) has a positive and statistically significant impact on growth in the sub-national level (Table 5 (GMM1)). This finding is similar to that of Hanushek (2016) in developing countries, Teixeira \& Queirós (2016b) in OECD countries, and Ogundari \& Awokuse (2018) in Sub-Saharan African countries.

Government spending has contributed positively towards regional economic growth. As shown in Table 5 (GMM1), government expenditures (gGE) have positive and statistically significant impact on sub-national growth. The finding is in line with the results found in OECD countries (Connolly \& $\mathrm{Li}_{\text {, }}$ 2016), in European Union countries (Sáez et al., 2017), in high-income and low-income countries (Chu et al., 2020) and in Indonesian provinces (Ambya, 2020).

Public spending on infrastructure is still not supportive towards sub-national growth. In contrary to the previous variables, public spending on infrastructure (gGEin) has a negative and significant impact towards growth in the sub-national level. (Table 5, GMM1). This indicates that public infrastructure spending has not yet contributed to sub-national growth. This result is in line with the conclusions by Ansar et al. (2016) in China and Shi et al. (2017) in sub-national areas in China.

Both foreign direct investments (FDI) and domestic investment (DDI) do not have a positive impact on growth in the sub-national areas. The estimates of the effect of FDI (gFDI) on sub-national economic growth are negative but insignificant (Table 5, GMM1). As a robustness check, GMM estimates are performed by replacing FDI with DDI (Table 5, GMM2). The estimates still show that DDI has insignificant impact on sub-national growth (Table 5, GMM2). This result is in accordance with that of Alvarado, Iniguez, \& Ponce (2017) in lower- 
middle income Latin American countries, Bakari (2018) for Algeria, Hayat (2018) in low and middleincome countries with a large natural resource sector, Asamoah, Mensah, \& Bondzie (2019) in SubSaharan African Countries, Bakari \& Sofien (2019) in Asian developing countries, Sokhanvar (2019) in five European Union member countries, and Faizah, Fasa, Suharto, Rahmanto, \& Athief (2019) in Indonesian provinces.

Labor has a positive and significant impact on growth in the sub-national level. The GMM estimates for the effect of labor $(\mathrm{gL})$ on regional economic growth are positive and statistically significant (Table 5). This result is in line with the findings by Abubakar \& Bala (2016) in India, Ramli et al. (2016) in Malaysia, and Bakari, Mabroukib, \& Othmani (2018) in Nigeria.

\section{Research Implication}

The main purpose of this analysis is to examine how important are health and education in boosting economic growth in the sub-national level. This issue is significant for a developing country such as Indonesia which achieved significant economic development, but it is still not evenly distributed among its regions. On the other hand, sub-national level governments' spending makes up half of total public spending in Indonesia.

The estimation results show that bank credit has a positive effect on economic growth in the subnational level. As shown in Table 5, bank has a positive and significant effect on economic growth (gPDRB) of provinces in Indonesia. The reason for this result is that bank credit provides funding for investment, which can increase the amount of capital stock in the economy, and thus increase economic growth (Sehrawat \& Giri, 2015b). In addition, banks provide funding for entrepreneurs, which enables them to implement innovative ideas, products and production processes. Ultimately this will increase innovation in the economy and boost economic growth (Belinga et al., 2016).

Health sector has positive impact in spurring the sub-national economy. As shown in Table 5, based on the panel GMM estimates, health outcome ( $\mathrm{gHl}$ ) has a positive and statistically significant influence on economic growth in the sub-national level (gPDRB). The rationale for this result is that improvement in health sector implies extending life expectancy (Leung \& Wanq, 2010), and extended life expectancy increases savings as well as physical and human capital formation. In turn, higher physical and human capital stock in the economy implies higher economic growth (Sharma, 2018). Furthermore, better health outcomes increases labor market participation and workers' productivity (Bloom, Canning, Kotschy, Prettner, \& Schünemann, 2019).

In addition, it was also found that health sector is highly important for boosting growth in the subnational economy. The panel GMM estimates in Table 5 shows that the impact of growth in health outcomes on economic growth in the provinces in Indonesia is approximately 40 times larger than the effect of bank credit on regional economic growth. This result highlights that public investment in human capital, in particular improving health outcomes is key to boosting sub-national growth. According to McCalman et al. (2018), this objective can be achieved by providing good quality public health services which targets improvements in health outcomes.

Similarly, education was found to have a positive and significant impact on sub-national economic growth. Based on the estimation results, the study found that the growth of education outcome (measured in years of schooling) (gEdu) has a positive and statistically significant impact on growth in the sub-national level (Table 5). A justification for this finding is that education, like health, is an investment channel to create human capital. While, more human capital makes labor is more productive and increases the rate of innovations in the economy, which in turn result in higher economic growth (Teixeira \& Queirós, 2016a).

Furthermore, increasing years of schooling, enhancing quality of education services, plus distributing it more equally among areas are important for boosting sub-national growth. As a note, some scholars such as Mendy \& Widodo (2018) found conflicting results to the above. The conflicting findings, in one hand, highlight that years of schooling in Indonesia is still relatively low. According to 2018 data from the Central Statistical Bureau of Indonesia (BPS), mean years of schooling by provinces range from 6.5 years in the province of Papua to 11 years in the capital city of Jakarta; while the national average is 8.3 years. Whereas, mean years of schooling in Germany, the US, the UK and OECD countries in 2018 were 14.1 years, 13.4 years, 13 years and 12 years respectively (United Nations 
Development Programme, 2019a; 2019b; 2019c; 2019d). On the other hand, in addition to years of schooling, the quality of education is important for the nexus between education and growth. Hanushek (2013) concluded that enhancing quality of schools is important in order for education to be able to enhance growth in developing countries. In relation to quality schools, the education service needs to be able to increase the cognitive skills of the students so they can contribute to growth (Hanushek, 2016). A revealing World Bank study found that $55 \%$ of Indonesian children who completed school are functionally illiterate. Being functionally illiterate means not being equipped with skills to enter the labor market; for example, being able to read but unable to comprehend the content. Whereas, the percentage of functional illiteracy in Vietnam and the OECD are $14 \%$ and $20 \%$ respectively (World Bank, 2018). Moreover, more years of schooling and higher quality education services needs to be distributed more equally among regions (Uddin \& Sarntisart, 2019). Thus, in order for education to continue to have a positive impact, or even increase its impact towards sub-national economic growth, years of schooling needs to be increased together with enhancing the quality of school service delivery. In particular, it must be ensured that the schools are able to sufficiently enhance the cognitive skills of the students. In addition, the enhancement of education outcome and educational service quality must be distributed more equally across all sub-national areas.

Government spending also contributes positively towards regional economic growth; however, the impact is small relative to health and education. As shown in Table 5, government expenditures (gGE) have positive and statistically significant impact on sub-national growth. Although the impact of government spending on sub-national growth is positive, its magnitude is miniscule compared to that of health and education. The reason that government spending has small impact on sub-national growth is that it may not have been sufficiently allocated to productive government spending such as providing quality education, increasing health outcome, and building highly needed public infrastructures. If instead this was the case, it would have increased the stock of human capital in the economy and enhance the productivity of existing private capital and would ultimately result in higher growth ( al., 2020). Thus, in order to boost sub-national growth, public spending needs to be allocated to activities which target enhancement of health and education outcomes by providing quality and equitable public health and educational services.

However, public spending on infrastructure is still not supportive towards sub-national growth. In contrary to the previous variables, public spending on infrastructure (gGEin) has a negative and significant impact towards growth in the sub-national level (Table 5). This finding indicates that public spending in infrastructure has not yet contributed to subnational growth. The argument for the negative relationship is that not only the quantity of infrastructure that matters, but also the quality and its usefulness (Chakamera \& Alagidede, 2018). If government spending was directed to build public infrastructures with sufficient quality and appropriate usefulness, this would increase the productivity of private (physical and human) capital, and ultimately would result in higher growth (Chu et al., 2020). Public infrastructure which are useful are those which encourage entrepreneurship and the private sector to thrive (Bennett, 2019), do not crowd-out private investment (Shi et al., 2017; Nguyen \& Trinh, 2018), and increase the productivity of private physical and human capital (Chu et al., 2020). Thus, in order for public spending on infrastructure to have positive impact on sub-national growth, it should be provided based on the needs of the private sector, complement private investments, and should be provided in sufficient quality.

It was also found that both Foreign direct investments (FDI) and domestic investment (DDI) do not have a positive impact on growth in the subnational areas. The GMM coefficient estimates of the effect of FDI (gFDI) on sub-national economic growth are negative but insignificant (Table 5). Similarly, the estimates show that DDI has insignificant impact on sub-national growth (Table 5 , GMM2). The rationale for this result is that the direction of relationship between investment and growth depends on the country's level of development, and the educational level of its citizens. Economies which are highly developed with high levels of education and human capital, the nexus between FDI and growth is positive. While for low and middle income countries with low levels of education and human capital, the nexus between FDI and growth is negative (Alvarado et al., 2017). It is 
known that the larger the amount of human capital that an economy has, the higher is the economy's capacity to absorb new technology from abroad, and to spur economic growth in the domestic economy (Datta \& Mohtadi, 2006). Thus, investment would have a positive impact on economic growth only if it is supported by sufficient human capital in the economy. Therefore, to enable investment to have a positive impact towards sub-national growth, increasing human capital is required by increasing health and educational outcomes. This can be achieved by directing more public funds to target increases in health and education outcomes.

Labor has a positive and significant impact on growth in the sub-national level. The estimates for the effect of labor $(\mathrm{gL})$ on regional economic growth is positive and statistically significant, but the magnitude is small compared to health and education (Table 5). The reason for the small magnitude for labor is that it is well known in economics that labor requires complementary factors to enhance its productivity. It is found that human capital enhances labor productivity (Benos \& Karagiannis, 2016), which in turn enhances economic growth (KaraalpOrhan, 2016). Therefore, government policy needs to be directed to increase labor productivity by increasing human capital. This can be achieved by allocating more public spending to activities which target the increase of health and educational outcome by providing quality public health and educational services equitably across all sub-national regions.

\section{CONCLUSION AND SUGGESTION}

By using a panel data from 33 provinces in Indonesia over the period from 2010 to 2018, and the GMM model, this study found that health, education, bank credit, government spending, and labor have a positive and significant effect on subnational economic growth. On the contrary, government expenditure on infrastructure was found to have a negative and statistically significant to sub-national economic growth in. Meanwhile, foreign and domestic investments failed to have a significant impact on sub-national economic growth. Furthermore, the estimation results showed that health and education outcomes significantly influenced economic growth in the sub-nationals as compared to other variables. The findings of our estimated model are robust with alternative model specification. The policy suggestions of the results are in order to dampen the negative effects of the current global economic downturn on the subnational economies, and to boost growth postdownturn period, the central and sub-national governments must focus on increasing human capital by maintaining or even increasing government spending aimed at improving health and education outcomes. This can be achieved by providing good quality public health services which enhances life expectancy.

In addition, the quality of public-school service delivery needs to be increased by ensuring that the schools are able to sufficiently enhance the cognitive skills of the students. Furthermore, good quality health and educational services need to be equally distributed across the all sub-national regions. Not only will such policy enhance human capital by increasing health and education outcomes, but it will also make domestic labor more productive, and generate the promised beneficial effect of FDI and DDI in boosting sub-national and national growth. Furthermore, such policy would be aligned with achieving the UN Sustainable Development Goals number 10: reducing inequality within a country.

\section{REFERENCES}

Abubakar, A. B., \& Bala, A. J. (2016). Nexus between domestic investment, FDI and economic growth: Empirical evidence from India. International Journal of Management, Accounting and Economics, 3(3), 174-184. Retrieved from http://www.ijmae.com/article_115239.html

Adawo, M. A. (2011). Has education (human capital) contributed to the economic growth of Nigeria? Journal of Economics and International Finance, 3(1), 46-58. https://doi.org/10.5897/JEIF.9000058

Afzal, M., Farooq, M. S., Ahmad, H. K., Begum, I., \& Quddus, M. A. (2010). Relationship between school education and economic growth in Pakistan: ARDL bounds testing approach to cointegration. Pakistan Economic and Social Review, 48(1), 39-60. Retrieved from https://www.jstor.org/stable/41762413?seq=1

Ahmed, K., Mahalik, M. K., \& Shahbaz, M. (2016). Dynamics between economic growth, labor, capital and natural resource abundance in Iran: An application of the combined cointegration 
approach. Resources Policy, 49, 213-221. https://doi.org/10.1016/j.resourpol.2016.06.005

Ali, W., \& Mna, A. (2019). The effect of FDI on domestic investment and economic growth case of three Maghreb countries. International Journal of Law and Management, 61(1), 91-105. https://doi.org/10.1108/IJLMA-09-2017-0214

Alvarado, R., Iniguez, M., \& Ponce, P. (2017). Foreign direct investment and economic growth in Latin America. " Economic Analysis and Policy, 56, 176-187.

https://doi.org/10.1016/j.eap.2017.09.006

Ambya, A. (2020). How government spending on public sector affect the economic growth?. JEJAK: Jurnal Ekonomi Dan Kebijakan, 13(1), 218-229. https://doi.org/10.15294/jejak.v13i1.21943

Ansar, A., Flyvbjerg, B., Budzier, A., \& Lunn, D. (2016). Does infrastructure investment lead to economic growth or economic fragility? Evidence from China. Oxford Review of Economic Policy, 32(3), 360-390. https://doi.org/10.1093/oxrep/grw022

Asamoah, L. A., Mensah, E. K., \& Bondzie, E. A (2019). Trade openness, FDI and economic growth in sub-Saharan Africa: do institutions matter?. Transnational Corporations Review, 11(1), 65-79. https://doi.org/10.1080/19186444.2019.1578156

Bakari, S. (2017). The impact of domestic investment on economic growth: New evidence from Malaysia. Journal of Smart Economic Growth, 2(2), 105-121. Retrieved from https://mpra.ub.uni-muenchen.de/79436/

Bakari, S. (2018). The impact of domestic investment on economic growth new policy analysis from Algeria. Bulletin of Economic Theory and Analysis, 3(1), 35-51. https://doi.org/10.25229/beta.337367

Bakari, S., Mabrouki, M., \& Othmani, A. (2018). The six linkages between foreign direct investment, domestic investment, exports, imports, labor force and economic growth: new empirical and policy analysis from Nigeria. Journal of Smart Economic Growth, 3(1), 25-43. Retrieved from https://jseg.ro/index.php/jseg/article/view/36

Bakari, S., \& Sofien, T. (2019). The impact of trade openness, foreign direct investment and domestic investment on economic growth: New evidence from Asian developing countries. Economic Research Guardian, 9(1), 46-54. Retrieved from https://www.ecrg.ro/files/p2019.9(1)2y3.pdf
Belinga, T., Zhou, J., Doumbe-Doumbe, E., Gahe, Z. S. Y., \& Koffi, Y. S. L. (2016). Causality relationship between bank credit and economic growth: Evidence from a time series analysis on a vector error correction model in Cameroon. Procedia-Social and Behavioral Sciences 2, No. 35 , https://doi.org/10.1016/j.sbspro.2016.11.061 664-671.

Benczúr, P., Karagiannis, S., \& Kvedaras, V. (2019). Finance and economic growth: financing structure and non-linear impact. Journal of Macroeconomics, 62, 1-28. https://doi.org/10.1016/j.jmacro.2018.08.001

Bennett, D. L. (2019). Infrastructure investments and entrepreneurial dynamism in the US. Journal of Business Venturing, 34(5), 1-28. https://doi.org/10.1016/j.jbusvent.2018.10.005

Benos, N., \& Karagiannis, S. (2016). Do education quality and spillovers matter? Evidence on human capital and productivity in Greece. Economic Modelling, 54, 563-573. https://doi.org/10.1016/j.econmod.2016.01.015

Biyase, M., \& Maleka, M. (2019). Life expectancy and economic growth: evidence from the Southern African development community. Economia Internazionale/International Economics, 72(3), 351-366. Retrieved from http://www.iei1946.it/ en/rivista-articolo.php?id=197

Bloom, D. E., Canning, D., Kotschy, R., Prettner, K., \& Schünemann, J. J. (2019). Health and economic growth: reconciling the micro and macro evidence. (No. w26003.). https://doi.org/10.3386/w26003

Chakamera, C., \& Alagidede, P. (2018). The nexus between infrastructure (quantity and quality) and economic growth in Sub Saharan Africa. International Review of Applied Economics, 32(5), 641-672. https://doi.org/10.1080/02692171.2017.1355356

Chu, T. T., Hölscher, J., \& McCarthy, D. (2020). The impact of productive and non-productive government expenditure on economic growth: an empirical analysis in high-income versus low-to middle-income economies. Empirical Economics, 58(5), 2403-2430. https://doi.org/10.1007/s00181-018-1616-3

Collin, M., \& Weil, D. N. (2020). The effect of increasing human capital investment on economic growth and poverty: A simulation exercise. Journal of Human Capital, 14(1), 43-83. https://doi.org/10.1086/708195 
Connolly, M., \& Li, C. (2016). Government spending and economic growth in the OECD countries. Journal of Economic Policy Reform, 19(4), 386395. https://doi.org/10.1080/17487870.2016.1213168

Datta, A., \& Mohtadi, H. (2006). Endogenous imitation and technology absorption in a model of North-South trade. International Economic Journal, 20(4), 431-459. https://doi.org/10.1080/10168730601027005

Dawood, T. C. (2018). Foreign interest rate, monetary policy and bank credit. Jurnal Ekonomi Pembangunan: Kajian Masalah Ekonomi Dan Pembangunan, 19(2), 138-155. https://doi.org/10.23917/jep.v19i2.5244

Dawood, T. C., Pratama, H., Masbar, R., \& Effendi, R. (2019). Does financial inclusion alleviate household poverty? Empirical evidence from Indonesia. Economics \& Sociology, 12(2), 235252. 789X.2019/12-2/14

Elia, A., Yulianto, Y., Tiawon, H., Sustiyah, S., \& Indrajaya, K. (2020). Government expenditure and poverty reduction in the proliferation of new administrative areas of Central Kalimantan, Indonesia. Journal of Socioeconomics and Development, 3(2), 145-155. https://doi.org/ $10.31328 /$ jsed.v3i2. 1410

Faggian, A., Modrego, F., \& McCann, P. (2019). Human capital and regional development. In Handbook of Regional Growth and Development Theories. Edward Elgar Publishing. https://books.google.co.id/books?id=LhEIwAEAC AAJ

Faizah, I., Fasa, M. I., Suharto, S., Rahmanto, D. N. A., \& Athief, F. H. N. (2019). Determinants of domestic direct investment in indonesia: islamic economic approach. JEJAK: Jurnal Ekonomi Dan Kebijakan, 12(2), 282-297. https://doi.org/10.15294/jejak.v12i2.20973

Gujarati, D. N., \& Porter, D. C. (2009). Basic Econometrics (Internatio). Mc Graw-Hill. https://books.google.co.id/books?id=hX7xoQEAC AAJ

Hadiwardoyo, W. (2020). Kerugian ekonomi nasional akibat pandemi Covid-19. Baskara: Journal of Business \& Entrepreneurship, 2(2), 83-92. Retrieve from https://jurnal.umj.ac.id/index.php/ baskara/article/view/6207

Hanushek, E. A. (2013). Economic growth in developing countries: The role of human capital. Economics of Education Review, 37, 204-212. https://doi.org/10.1016/j.econedurev.2013.04.00 5

Hanushek, E. A. (2016). Will more higher education improve economic growth?. Oxford Review of Economic Policy, 32(4), 538-552. https://doi.org/10.1093/oxrep/grw025

Hartarska, V., Nadolnyak, D., \& Shen, X. (2015). Agricultural credit and economic growth in rural areas. Agricultural Finance Review, 75(3), 302312. https://doi.org/10.1108/AFR-04-2015-0018

Hayat, A. (2018). FDI and economic growth: the role of natural resources?. Journal of Economic Studies, 45(2), 283-295. https://doi.org/10.1108/JES-05-2015-0082

He, L., \& Li, N. (2020). The linkages between life expectancy and economic growth: some new evidence. Empirical Economics, 58(5), 23812402. https://doi.org/10.1007/s00181-018-16127

Hlavacek, P., \& Bal-Domanska, B. (2016). Impact of foreign direct investment on economic growth in Central and Eastern European countries. Engineering Economics, 27(3), 294-303. https://doi.org/10.5755/j01.ee.27.3.3914

Ismayilov, A., Kasumov, A., \& Ahmadova, E. (2020). Education and economic growth: the Case of Azerbaijan. 55th International Scientific Conference on Economic and Social Development - Baku, 18-19 June, 2020. 581-587. Retrieve from https://www.esdconference.com/upload/book_of_abstracts/Book of_Abstracts_esdBaku2020_Vol4_Online.pdf

Judith, M. N., Ugwuegbe, S., \& Ugwuoke, R. O. (2014). The impact of bank credit on the growth of Nigerian economy: A co integration approach. Research Journal of Finance and Accounting, 5(10), 87-95. Retrieve from https://www.iiste.org/Journals/index.php/RJFA/ar ticle/download/13060/13607

Karaalp-Orhan, H. S. (2016). Human capital, labor productivity and economic growth: The bounds and causality tests for Turkey. International Congress on Politic, Economic and Social Studies (ICPESS ) No. 1. Retrieve from http://www.registericpess.org/index.php/ICPESS/ article/view/2219

Leung, M. C., \& Wang, Y. (2010). Endogenous health care, life expectancy and economic growth. Pacific Economic Review, 15(1), 11-31. https://doi.org/10.1111/j.14680106.2009.00486.x 
Pribac, L., \& Anghelina, A. (2015). Human capital the effects of education on economic growth within the European Union. Studia Universitatis "Vasile Goldis" Arad - Economics Series, 25(3), 35-44. https://doi.org/10.1515/sues-2015-0020

Lubis, C. A. B. E. (2014). Pengaruh jumlah tenaga kerja, tingkat pendidikan pekerja dan pengeluaran pendidikan terhadap pertumbuhan ekonomi. Jurnal Economia, Vol. 10, No. 2., 10(2). https://doi.org/10.21831/economia.v10i2.7544

Maryanti, S., Netrawati, I. G. A. O., \& Nuada, I. W. (2020). Pandemi COVID-19 dan implikasinya pada perekonomian NTB. Media Bina Ilmiah, 14(11), 3497-3508. Retrieve from https://ejurnal.binawakya.or.id/index.php/MBI/art icle/view/573

McCalman, J., Bailie, R., Bainbridge, R., McPhail-Bell, K., Percival, N., Askew, D., ... Tsey, K. (2018). Continuous quality improvement and comprehensive primary health care: a systems framework to improve service quality and health outcomes. Frontiers in Public Health 6, 76(6). https://doi.org/10.3389/fpubh.2018.00076

Mendy, D., \& Widodo, T. (2018). Do education levels matter on Indonesian economic growth? Economics \& Sociology, 11(3), 133-146. https://doi.org/10.14254/2071-789X.2018/11-3/8

Musa, M., \& Jelilov, G. (2016). The impact of government expenditure on economic growth in Nigeria. Sacha Journal of Policy and Strategic Studies, 15(2), 15-23.

Nguyen, C. T., \& Trinh, L. T. (2018). The impacts of public investment on private investment and economic growth. Journal of Asian Business and Economic Studies, 25(1), 15-32. https://doi.org/10.1108/JABES-04-2018-0003

Nugroho, I. (2020). Fostering online social capital during the COVID-19 pandemic and new normal. Journal of Socioeconomics and Development, 3(2), 74-78. https://doi.org/ 10.31328/jsed.v3i2.1640

Ogundari, K., \& Awokuse, T. (2018). Human capital contribution to economic growth in Sub-Saharan Africa: does health status matter more than education? Economic Analysis and Policy, 58, 131-140. https://doi.org/10.1016/j.eap.2018.02.001

Önder, Z., \& Özyıldırım, S. (2013). Role of bank credit on local growth: Do politics and crisis matter? Journal of Financial Stability, 9(1), 13-25. https://doi.org/10.1016/j.jfs.2012.12.002
Panjawa, J. L., Samudro, B. R., \& Soesilo, A. M. (2018). Regional economic disparities in Eastren Indonesia and determinants: Comparative analysis of origin district and new district. Regional Science Inquiry, 10(1), 117-124.

Putri, P. I. (2014). Pengaruh investasi, tenaga kerja, belanja modal, dan infrastruktur terhadap pertumbuhan ekonomi Pulau Jawa. JEJAK: Jurnal Ekonomi Dan Kebijakan, 7(2). https://doi.org/10.15294/jejak.v7i2.3892

Ramli, N. R., Hashim, E., \& Marikan, D. A. A. (2016). Relationship between education expenditure, capital, labor force and economic growth in Malaysia. International Journal of Academic Research in Business and Social Sciences, 6(12), 459-468. https://doi.org/10.6007/ijarbss/v6i12/2510

Sáez, M. P., Álvarez-García, S., \& Rodríguez, D. C. (2017). Government expenditure and economic growth in the European Union countries: New evidence. Bulletin of Geography. Socio-Economic Series 3, 6(36), 127-133. https://doi.org/10.1515/bog-2017-0020

Safira, S., Djohan, S., \& Nurjanana, N. (2019). Pengaruh pengeluaran pemerintah pada bidang infrastruktur pendidikan dan kesehatan terhadap pertumbuhan ekonomi di provinsi kalimantan timur. FORUM EKONOMI, 21(2), 211-216. https://doi.org/10.1515/bog-2017-0020

Saidi, S., Shahbaz, M., \& Akhtar, P. (2018). The longrun relationships between transport energy consumption, transport infrastructure, and economic growth in MENA countries. Transportation Research Part A: Policy and Practice, 111, 78-95. https://doi.org/10.1016/j.tra.2018.03.013

Sehrawat, M., \& Giri, A. K. (2015a). The role of financial development in economic growth: empirical evidence from Indian states. International Journal of Emerging Markets, 10(4), 765-780. https://doi.org/10.1108/IJoEM-052014-0064

Sehrawat, M., \& Giri, A. K. (2015b). The role of financial development in economic growth: empirical evidence from Indian states. International Journal of Emerging Markets, 10(4), 765-780. https://doi.org/10.1108/IJoEM-052014-0064

Sharma, R. (2018). Health and economic growth: Evidence from dynamic panel data of 143 years. PloS One, 13(10), 1-20. https://doi.org/10.1371/journal.pone.0204940 
Shi, Y., Guo, S., \& Sun, P. (2017). The role of infrastructure in China's regional economic growth. Journal of Asian Economics, 49, 26-41. https://doi.org/10.1016/j.asieco.2017.02.004

Silalahi, D. E., \& Ginting, R. R. (2020). Strategi kebijakan fiskal pemerintah indonesia untuk mengatur penerimaan dan pengeluaran negara dalam menghadapi pandemi Covid-19. Jesya (Jurnal Ekonomi \& Ekonomi Syariah), 3(2), 156167. https://doi.org/10.36778/jesya.v3i2.193

Soedarmono, W., Hasan, I., \& Arsyad, N. (2017). Non-linearity in the finance-growth nexus: Evidence from Indonesia. International Economics, 150, 19-35. https://doi.org/10.1016/j.inteco.2016.11.003

Sokhanvar, A. (2019). Does foreign direct investment accelerate tourism and economic growth within Europe? Tourism Management Perspectives, 29, 86-96. https://doi.org/10.1016/j.tmp.2018.10.005

Spiteri, J., \& Von Brockdorff, P. (2019). Economic development and health outcomes: Evidence from cardiovascular disease mortality in Europe. Social Science \& Medicine, 224, 37-44. https://doi.org/10.1016/j.socscimed.2019.01.050

Teixeira, A. A., \& Queirós, A. S. (2016a). Economic growth, human capital and structural change: A dynamic panel data analysis. Research Policy, 45(8), https://doi.org/10.1016/j.respol.2016.04.006

Teixeira, A. A., \& Queirós, A. S. (2016b). Economic growth, human capital and structural change: A dynamic panel data analysis. Research Policy, 45(8), 1636-1648. https://doi.org/10.1016/j.respol.2016.04.006

Uddin, M. N., \& Sarntisart, S. (2019). Human capital inequality and economic growth: evidence with sub-national data from Thailand. International Journal of Social Economics, 46(7), 938-956. https://doi.org/10.1108/IJSE-07-2018-0368
Umar, D. I. (2017). Education outcomes, health outcomes and economic growth in Nigeria (19802013). " Energy Economics Journal of Social and Economic Development, 19(1), 227-244. https://doi.org/10.1007/s40847-017-0039-x

United Nations Development Programme. (2019a). Inequalities in Human Development in the 21st Century: Briefing note for countries on the 2019 Human Development Report_Japan. Retrieved from http://hdr.undp.org/sites/all/themes/ hdr_theme/country-notes/JPN.pdf

United Nations Development Programme. (2019b). Inequalities in Human Development in the 21st Century: Briefing note for countries on the 2019 Human Development Report-Germany. Retrieved from http://hdr.undp.org/sites/all/themes/ hdr_theme/country-notes/DEU.pdf

United Nations Development Programme. (2019c). Inequalities in Human Development in the 21st Century: Briefing note for countries on the 2019 Human Development Report-United Kingdom.

United Nations Development Programme. (2019d). Inequalities in Human Development in the 21st Century: Briefing note for countries on the 2019 Human Development Report-United States.

World Bank. (2018). Indonesian Economic Quaterly: Learning More, Growing Faster. Retrieved from https://openknowledge.worldbank.org/bitstream/ handle/10986/29921/126891-WP-PUBLIC-on-6-518.pdf?sequence $=1$ \&isAllowed $=y$

Yudawisastra, H. G., Manurung, D. T. H., \& Husnatarina, F. (2018). Relationship between value added capital employed, value added human capital, structural capital value added and financial performance. Investment Management and Financial Innovations, 15(2), 222-231. https://doi.org/10.21511/imfi.15(2).2018.20 